[Case Report]

\title{
A Case of Marine-Lenhart Syndrome with Predominance of Plummer Disease
}

\author{
Megumi MiYazaki*, Yosuke OKada, Keiichi Torimoto and Yoshiya TanaKa \\ First Department of Internal Medicine, School of Medicine, University of Occupational and Environmental Health, \\ Japan. Yahatanishi-ku, Kitakyushu 807-8555, Japan
}

\begin{abstract}
A 74-year-old woman with a left neck mass and thyrotoxicosis was referred to our hospital, and was later diagnosed with Marine-Lenhart syndrome based on positivity for thyroid autoantibodies, ultrasonographically evident left lobe thyroid nodule with increased blood flow, and scintigraphically identified not only increased tumorlike accumulation but also diffused uptake. Disease control was difficult despite administration of antithyroid drugs, so subtotal thyroidectomy was performed. No hyperplastic changes or histopathological findings characteristic of Graves disease were evident on histopathology, so Plummer disease was considered to be dominant. In case of hot in low type which showed higher uptake in the nodule and lower uptake in the extranodular part on scintigraphy, there is a possibility of relapse in drug treatment.
\end{abstract}

Keywords : Marine-Lenhart syndrome, Plummer disease, Graves disease.

(Received July 6, 2017, accepted April 11, 2019)

\section{Introduction}

Marine-Lenhart syndrome was first described by Marine and Lenhart in 1911 as a syndrome of the combination of Graves disease and functioning thyroid nodules [1]. While $11.2-12.8 \%$ of patients with Graves disease have nodular lesions, only $0.8-2.7 \%$ of those with Graves disease have functioning thyroid nodules [2-3]. To our knowledge, only a few studies have provided details about this clinical condition. To date, many aspects of the pathogenesis of MarineLenhart syndrome remain unknown, and no standard treatment has yet been established. We report a patient with Marine-Lenhart syndrome in whom Plummer disease, also known as toxic multinodular goiter, was the dominant feature on histopathological examination.

\section{Case Report}

The patient was a 74-year-old woman who had been treated for diabetes and hyperlipidemia since she was 60 years old. Although a neck mass was noted at age 73 years, she was treated conservatively because thyroid function tests were normal at that time. The patient was referred to our hospital in June 2010 due to $4 \mathrm{~kg}$ weight loss within the preceding 6 months and results of tests that showed thyroid hyperfunction (thyroid-stimulating hormone (TSH): $0.004 \mu \mathrm{U} / \mathrm{ml}$, free triiodothyronine (FT3): $6.5 \mathrm{pg} / \mathrm{m} l$, and free thyroxine (FT4): $1.9 \mathrm{ng} / \mathrm{d} l$ ).

Physical examination showed body height $143 \mathrm{~cm}$, weight $38.5 \mathrm{~kg}$, blood pressure $120 / 76 \mathrm{mmHg}$, and pulse rate $104 \mathrm{bpm}$ and regular. The patient was alert with no exophthalmos. Palpation identified a non-tender firm nodule $(50 \times 32 \mathrm{~mm})$ with a smooth surface on the left lobe of the thyroid gland, but no lymphadenop-

*Corresponding Author: Megumi MrYAZAKI, First Department of Internal Medicine, School of Medicine, University of Occupational and Environmental Health, Japan. Yahatanishi-ku, Kitakyushu 807-8555, Japan, Tel: +81-93-603-1611, Fax: +81-93-691-9334, E-mail: megmatsuda@med.uoeh-u.ac.jp 
athy was noted in the surrounding area. Auscultation of the chest and heart was normal. Finger tremor and lower limb edema were negative.

Laboratory tests on admission showed normal hepatic and renal function and no electrolyte abnormalities (Table 1). Thyroid function tests showed thyroid hyperfunction (TSH: $0.01 \mu \mathrm{U} / \mathrm{ml}$, FT3: $5.44 \mathrm{pg} / \mathrm{ml}$, FT4: $2.18 \mathrm{ng} / \mathrm{d} l$ ), and positivity for TSH receptor antibodies (TRAb). Based on these findings, the provisional diagnosis was autoimmune thyroid disease.

Ultrasonography showed a cystic nodule with increased peripheral blood flow in the left lobe of the thyroid gland (Fig. 1), but no enlargement or nodule in the right lobe. ${ }^{99 \mathrm{~m}}$ Technetium (Tc) scintigraphy showed higher uptake corresponding to the nodule in the left lobe, with lower uptake around it but no perfusion defect (Fig. 2). The nodule contained a lower uptake part, and it was considered a cyst. There was a clear difference between the nodule and the extranodular part, hot in low pattern.

Based on the guidelines for the diagnosis of Graves disease [4] (e.g. clinical findings such as tachycardia and weight loss, high FT3 and FT4 levels, low TSH

Table 1. Results of laboratory tests on admission

\begin{tabular}{llll}
\hline $\begin{array}{l}\text { Peripheral blood } \\
\text { White blood cells }\end{array}$ & $5300 / \mu l$ & Sodium & $139 \mathrm{mEq} / l$ \\
Red blood cells & $433 \times 10^{4} / \mu l$ & Potassium & $101 \mathrm{mEq} / l$ \\
Hemoglobin & $12.4 \mathrm{~g} / \mathrm{d} l$ & C-reactive protein & $0.08 \mathrm{mg} / \mathrm{d} l$ \\
Platelets & $19.0 \times 10^{4} / l$ & ESR & $16 \mathrm{~mm} / \mathrm{h}$ \\
& & & \\
Blood biochemistry & & Thyroid function test \\
Total protein & $7.2 \mathrm{~g} / \mathrm{d} l$ & TSH & $0.01 \mu \mathrm{U} / \mathrm{m} l$ \\
Albumin & $4.1 \mathrm{~g} / \mathrm{d} l$ & FT3 & $5.44 \mathrm{pg} / \mathrm{m} l$ \\
Aspartate aminotransferase & $20 \mathrm{U} / l$ & FT4 & $2.18 \mathrm{ng} / \mathrm{d} l$ \\
Alanine aminotransferase & $24 \mathrm{U} / l$ & TRAb & $25.8 \mathrm{U} / \mathrm{m} l$ \\
$\gamma$-glutamyltranspeptidase & $18 \mathrm{U} / l$ & Tg-Ab & $0.6 \mathrm{U} / \mathrm{m} l$ \\
ALP & $194 \mathrm{IU} / l$ & TPO-Ab & $<0.3 \mathrm{U} / \mathrm{m} l$ \\
Total cholesterol & $151 \mathrm{mg} / \mathrm{d} l$ & TSAb & $116 \%$ \\
Blood urea nitrogen & $23 \mathrm{mg} / \mathrm{d} l$ & Tg & $30.7 \mathrm{ng} / \mathrm{m} l$ \\
Creatinine & $0.46 \mathrm{mg} / \mathrm{d} l$ & & \\
\hline
\end{tabular}

ALP: Alkaline Phosphatase, ESR: Erythrocyte sedimentation rate, TSH: Thyroid stimulating hormone, FT3: Free triiodothyronine, FT4: Free thyroxine, TRAb: TSH receptor antibody, Tg-Ab: anti-thyroglobulin antibody, TPO-Ab: anti thyroperoxidase antibody, TSAb: thyroid stimulating antibody, Tg: thyroglobulin level, and positivity for autoantibodies) and the diffuse uptake on scintigraphy, the established diagnosis was Graves disease. The patient was also considered to have Plummer disease since scintigraphy showed accumulation of high levels of radioactive iodine corresponding to the tumor mass. Accordingly, the final diagnosis was Marine-Lenhart syndrome.

Treatment with thiamazole was started because the patient refused to undergo surgery, but it was discontinued following the appearance of pruritus (Fig. 3). We started treatment with propylthiouracil (PTU) at $150 \mathrm{mg} /$ day in November 2010, which resulted in the

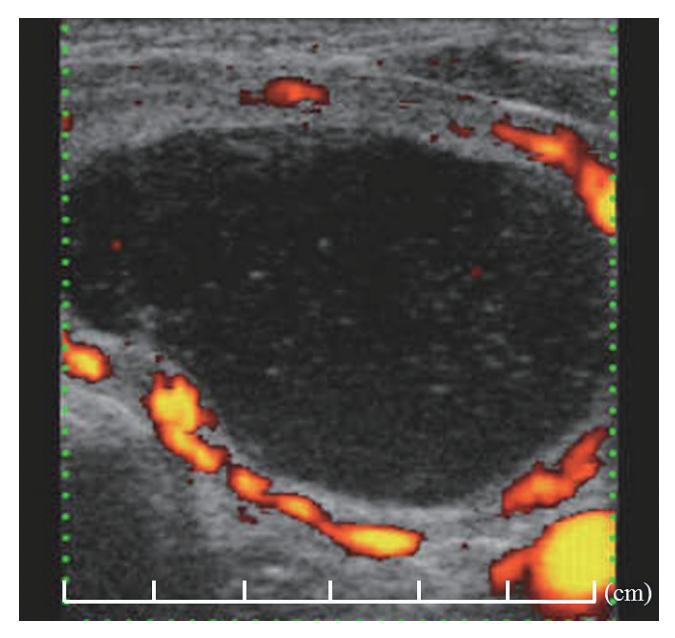

Fig. 1. Thyroid ultrasonography showed a cystic nodule. Thyroid ultrasound showed a solitary cystic nodule with increased peripheral blood flow.

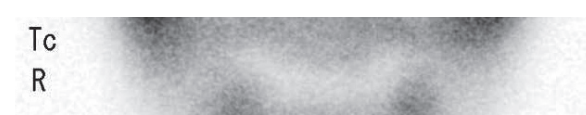

Fig. 2. Thyroid scintigraphy showed higher uptake. Thyroid scintigraphy showed higher uptake corresponding to the nodule in the left lobe surrounded by diffuse lower uptake in the bilateral lobe without perfusion defect. The nodule contained a lower uptake part. 


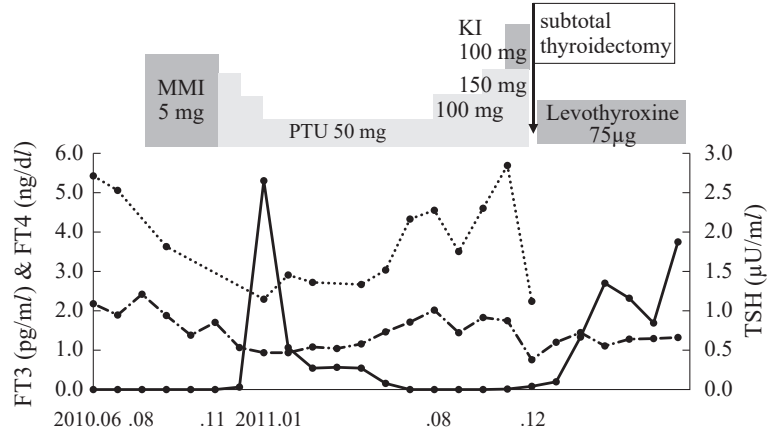

Fig. 3. Clinical course of thyroid function. Treatment with thiamazole (MMI) at $5 \mathrm{mg}$ /day was started, but the drug was withdrawn and replaced with propylthiouracil (PTU) due to the occurrence of pruritus. Thyroid function tests normalized within 2 months. The patient continued to be treated with $50 \mathrm{mg} /$ day PTU, but thyrotoxicosis recurred in August 2011. Subtotal thyroidectomy was conducted in December 2011. Surgery was followed by normalization of thyroid function under $75 \mu \mathrm{g}$ /day levothyroxine. No recurrence has been observed since operation. FT3: free triiodothyronine, FT4: free thyroxine, TSH: thyroid stimulating hormone, MMI: thiamazole, PTU: propylthiouracil, KI: potassium Iodide. ..* : FT3, $\cdots$ : FT4, $\rightarrow$ : TSH.

normalization of thyroid function, and the dose was subsequently reduced to $50 \mathrm{mg} /$ day. However, recurrence was observed in August 2011 (TSH $<0.01 \mu \mathrm{U} /$ $\mathrm{m} l$, FT3: $4.5 \mathrm{pg} / \mathrm{m} l$, FT4: $2.02 \mathrm{ng} / \mathrm{d} l$, TRAb: $21.3 \mathrm{U} /$ $\mathrm{ml}$ ). The dose of PTU was increased back to $150 \mathrm{mg} /$ day, but was found to be ineffective in the normalization of thyroid function.

Consequently, subtotal thyroidectomy was performed in December 2011. A $7 \mathrm{~cm}$ cystic nodule was observed (Fig. 4A); the left lobe of the thyroid gland was resected with a part of the right lobe that was preserved.

The resected left lobe contained a solitary cyst, consistent with the scintigraphy findings (a single hypoperfusion inside the nodule). Histopathological examination of the cystic tumor showed follicular adenoma and fibrous capsule (Fig. 4B). No hyperplastic thyroid tissue was observed apart from the tumor, the follicles around the tumor were small, and the histopathological findings were negative for the characteristic features of Graves disease, such as papillary growth, even in the right lobe (Fig. 4C). The patient showed satisfactory progress postoperatively and the euthyroid state was maintained with $75 \mu \mathrm{g}$ of levothyroxine.
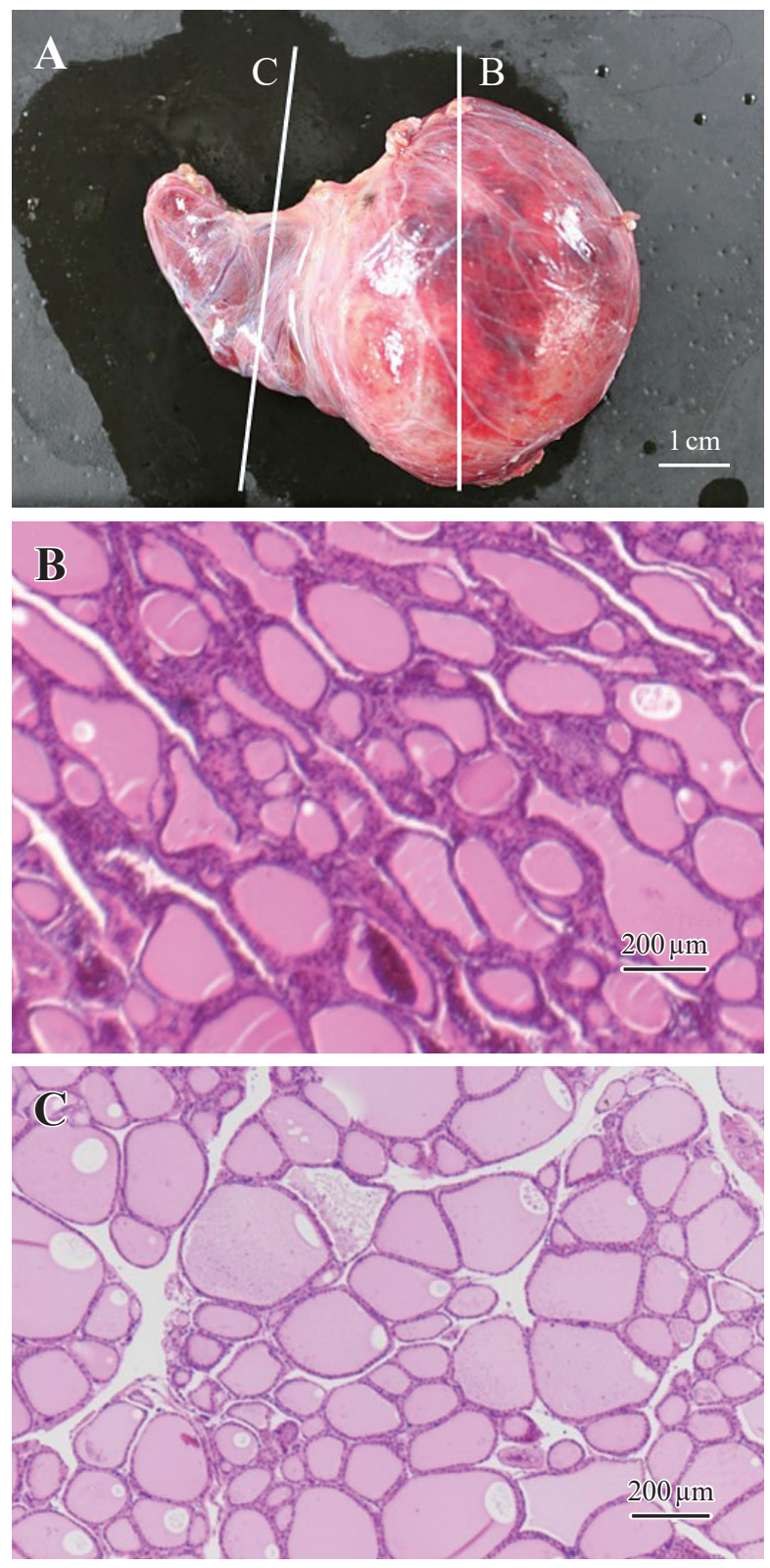

Fig. 4. Surgical and histopathological findings of thyroid. A: The left lobe contained a solitary cyst. B: Light microscopic findings. Left lobe, nodular part. Several anaplastic follicular structures of various sizes were found in the periphery under the capsule. Interstitial edema, hyalinization and follicular structure were observed at the periphery of the nodule, and lymphoid infiltration forming lymphoid follicles was observed around the tumor. Note the lack of columnar epithelial cells and papillary growth. Hematoxylin and eosin staining. C: Light microscopic findings. Right lobe, extranodular part. No hyperplastic thyroid tissue and papillary growth was observed, and the follicles around the tumor were small. 


\section{Discussion}

We described a patient with Marine-Lenhart syndrome, together with dominant Plummer disease, as confirmed by histopathological examination.

Marine-Lenhart syndrome is defined as Graves disease with thyroid nodular lesions and clinical characteristics of both Graves disease and Plummer disease [5]. Thyroid gland enlargement and one or more functioning nodules are observed by imaging, and these nodules are histopathologically benign. Our patient was diagnosed with Marine-Lenhart syndrome, since she met the diagnostic criteria for Graves disease and had a functioning nodule.

To our knowledge, nine patients who underwent surgery for Marine-Lenhart syndrome have been reported [6-14]. In the patients in whom characteristic findings of Graves disease were observed by histopathological examination, scintigraphy showed hot in high pattern, increased uptake of radioactivity in both lobes and the nodule, and the nodule can not be distinguished from the extranodular part [13]. In our case and Aoyama's case [14], scintigraphy showed accumulation at the site that corresponded to that of the nodule and normal uptake around it, hot in low pattern. The histopathological test showed no findings characteristic of Graves disease, such as high columnar follicular epithelium or resorption vacuoles. These findings were suggestive of Plummer disease. Importantly, there are no apparent differences between both diseases with regard to thyroid function and thyroid ultrasound findings, but scintigraphy is considered to allow better distinction between the two conditions. Further studies are expected in the cases in which scintigraphy showed hot in low type.

There is no currently established treatment for Marine-Lenhart syndrome. In previous studies in which surgery was conducted [6-14], surgery was performed after attempts to control thyroid function with antithyroid drugs. Those studies reported that euthyroid state could be maintained with antithyroid drugs in all patients except two who underwent surgery at the early stage of the disease after the initiation of drug treatment $[8,14]$, and one who discontinued antithyroid drugs [13]. In contrast, our patient underwent surgery because maintenance of normal thyroid function became difficult following recurrence during treatment with PTU. For patients with dominant Plummer disease, like our patient, thyroidectomy or treatment with radioactive iodine therapy during the early stage may be necessary, instead of antithyroid drugs. Furthermore, Sasaki reported about nonsurgical treatment in which one was replaced with antithyroid drugs and three of five cases eventually required radiation iodine therapy in patients for whom scintigraphy showed hot in low type [15]. That is consistent with our interpretation.

We encountered a case of Marine-Lenhart syndrome with histopathological findings of Plummer disease. Many aspects of the pathogenesis of this disease remain unknown, and treatment strategy has not yet been established. In cases of hot in low type with scintigraphy, when there is a type of plummer disease dominance there is a possibility of relapse in drug treatment.

\section{Conflict of Interest}

The authors declare no conflict of interest.

\section{References}

1. Marine D \& Lenhart CH (1911): Pathological anatomy of exophthalmic goiter: The anatomical and physiological relations of the thyroid gland to the disease; the treatment. Arch Intern Med 8: 265-316

2. Carnell NE \& Valente WA (1998): Thyroid nodules in Graves' disease: Classification, characterization, and response to treatment. Thyroid 8: 647-652

3. Charkes ND (1972): Graves' disease with functioning nodules (Marine-Lenhart syndrome). J Nucl Med 13: 885-892

4. Mitsuma T, Shishiba Y, Uchimura H et al (2002): Guidelines for the diagnosis of thyroid diseases: Basedow's disease, hypothyroidism, indolent thyroiditis / chronic thyroiditis (Hashimoto's disease) and subacute thyroiditis. Clinical Endocrinology 50: 643-653 (in Japanese)

5. Braga-Basaria M \& Basaria S (2003): Marine-Lenhart syndrome. Thyroid 13: 991

6. Nishikawa M, Yoshimura M, Yoshikawa N et al (1997): Coexistence of an autonomously functioning thyroid nodule in a patient with Graves' disease: An unusual presentation of Marine-Lenhart syndrome. Endocr J 44: 571-574 
7. Cakir M (2005): Marine-Lenhart syndrome. J Natl Med Assoc 97: 1036-1038

8. Kurozumi S, Matsumoto H, Ohya T et al (2012): A case of Marine-Lenhart syndrome revealing good course after thyroidectomy. Official Journal of the Japan Association of Endocrine Surgeons and the Japanese Society of Thyroid Surgery 29: 76-79 (in Japanese)

9. Scherer T, Wohlschlaeger-Krenn E, Bayerle-Eder M, Passler C, Reiner-Concin A, Krebs M \& Gessl A (2013): A case of simultaneous occurrence of Marine-Lenhart syndrome and a papillary thyroid microcarcinoma. BMC Endocr Disord 13: 16

10. Motoo I, Kahara T, Shima K, Usuda R \& Hishinuma A (2013): A case of Marine-Lenhart syndrome following thyroid functioning adenoma. Intern Med 111. Nankodo, Tokyo pp 1021-1024 (in Japanese)

11. Şen Y, Cimbek EA, Yuca SA, Gedik GK \& Sarı O (2014): Marine-Lenhart syndrome in a young girl. J Pediatr Endocrinol Metab 27: 189-191

12. Uludag M, Aygun N, Ozel A, Yener Ozturk F, Karasu R,
Ozguven BY, Citgez B, Mihmanli M \& Isgor A (2016): A rare presentation of autonomously functioning papillary thyroid cancer: Malignancy in Marine-Lenhart syndrome nodule. Case Rep Surg 2016: 8740405

13. Konno N, Hirokawa J \& Abe S (1988): A case of Graves' disease associated with an autonomously functioning thyroid nodule (AFTN) (Marine-Lenhalt Syndrome) which spontaneously became a cold nodule. Endocrinol Jpn 35: 753-758

14. Aoyama M, Yamasaki S, Tsuyuguchi M, Hino N, Miyoshi T \& Tsuboi M (2013): A case of Marine-Lenhart syndrome with papillary carcinoma located in the autonomous hyperfunctioning thyroid nodule. Official Journal of the Japan Association of Endocrine Surgeons and the Japanese Society of Thyroid Surgery 30: 82-86 (in Japanese)

15. Sasaki J (2014): TSH-hypersensitive thyroid may cause hyperthyroidism (a hypothesis). Official Journal of the Japan Association of Endocrine Surgeons and the Japanese Society of Thyroid Surgery 31: 303-309 
プランマー病の病勢が優位と考えられたマリンーレンハルト症候群の1例

宮﨑 恵, 岡田 洋右, 鳥本 桂一, 田中 良哉

産業医科大学 医学部 第 1 内科学講座

要旨：症例は74歳, 女性, 左頸部腫瘤および甲状腺中毒症を認め, 当院を受診, 甲状腺自己抗体陽性, 頸部工 コーにて血流光進像を伴う甲状腺左葉の結節を認め, シンチグラフィで腫瘤状の集積光進像と周囲のびまん性の弱 い集積を認め, マリンーレンハルト症候群と診断した。抗甲状腺薬で加療されたがコントロール困難となり, 甲状腺 亜全摘術を施行した。病理組織像は, 過形成変化やバセドウ病に特徵的な組織所見を認めなかった。以上からプラ ンマー病の病勢が優位であったと考えられた。シンチグラフィで腫瘤に強い集積と周囲にびまん性の弱い集積を認 める Hot in low型の症例では, 内服治療では再燃する可能性がある.

キーワード：マリンーレンハルト症候群, プランマー病, バセドウ病.

J UOEH(産業医大誌) 41 (2)：165 - 170 (2019) 